\title{
C-C Chemokine Receptor Type 7
}

National Cancer Institute

\section{Source}

National Cancer Institute. C-C Chemokine Receptor Type 7. NCI Thesaurus. Code C104130.

C-C chemokine receptor type 7 (378 aa, $\sim 43 \mathrm{kDa}$ ) is encoded by the human CCR7 gene. This protein plays a role in memory $\mathrm{T}$-cell migration and dendritic cell maturation. 